\title{
Mapping Practices and Technologies of Climate-Smart Agriculture in Bangladesh
}

\author{
M. Mahashin and R. Roy * \\ Department of Agricultural Extension and Information System \\ Sher-e-Bangla Agricultural University, Dhaka \\ * Corresponding author: ranjansau@yahoo.com
}

\begin{abstract}
Climate-Smart Agriculture (CSA) is an integrative approach of increasing productivity, enhancing resilience, and minimizing greenhouse gas emissions. The study addresses four research questions: (I) How many agro-region based climate change hot spots are there in Bangladesh with specific reference to CSA, (II) what are the contribution of practices and technologies of CSA? (III) How institutional involvement promoting CSA practices and technologies? A mixed method, i.e. literature review, discussion with experts, gathering information from the DAE, was employed to carry out the study. Results indicate that farmers have been practicing CSA at a smaller-scale and investment on knowledge, learning and capacity development is a key means for a full-scale CSA implementation. Findings illustrate that broad types of practices and technologies have been addressing three intertwined challenges: ensuring food security, impacts of climate change on agriculture and agricultureôs impact on climate change. The governmentôs project-based endeavor of implementing CSA marks that they have been pledged to defeat the climatic risks in agriculture. Active initiative for mainstreaming CSA into national policies and programs are inadequate.
\end{abstract}

Key words: Climate change hot spots, Food security, Mainstreaming CSA, Scaling up technologies

\section{Introduction}

Business-as-usual scenarios of population growth and food consumption patterns indicate that agricultural production will need to increase by $70 \%$ by 2050 to meet global demand for food (World Bank, 2012). Global agriculture must therefore transform itself if it is to feed a growing global population and provide the basis for economic growth and poverty reduction (Roy et al., 2013). Climate change will make this task more difficult under a business-as-usual scenario, due to adverse impacts on agriculture, requiring spiraling adaptation and related costs. Bangladesh is one of the most vulnerable countries in the world considered to be the highest victim of climate change effect. Flooding, for example, is a vital climatic hazard in the North-Eastern Bangladesh, which aggravates the existing stresses (e.g., unemployment) and impedes socio-economic development (MoEF, 2005). Ahmed and Suphachalasai (2014) projected that Bangladesh could see climate change losses of up to 9\% of GDP by the end of the century. It is projected that the magnitude of the impacts of climate change on agriculture will be more severe, which will aggravate countryós poverty, food insecurity and socio-economic problems (World Bank, 2012). For the same reasons, Bangladesh would experience a net increase in poverty of approximately 15\% by 2030 (World Bank, 2012). In this dire condition, climate-smart agriculture (CSA), a new approach, is particularly useful for achieving food security and agricultural development goals, adaptation to climate, and lowering greenhouse gases (e.g. $\mathrm{CH}_{4}$ and $\mathrm{CO}_{2}$ ) emissions from farming production (MoEF, 2005; FAO, 2013; Roy et al., 2015).

Climate-smart agriculture (CSA) is an effective approach for transforming and reorienting agricultural development under the new realities of climate change (Lipper et al., 2014). FAO (2013) reported CSA as ñagriculture that sustainably increases productivity, enhances resilience (adaptation), reduces/removes GHGs (mitigation) where possible, and enhances achievement of national food security and development goalsò. These definitions, therefore, illustrate the three pillar of CSA, namely, productivity, adaptation and mitigation as well as key characteristics of CSA like it addresses climate change, maintains ecosystems services, and integrates multiple goals. CSA as defined and presented by FAO at the Hague Conference on Agriculture, Food Security and Climate Change in 2010, that contributes to the achievement of sustainable development goals (FAO, 2013). CSA is an integrated approach to address these interlinked challenges of food security and climate change that explicitly aims for three objectives (i) sustainably increasing agricultural productivity to support equitable increases in farm incomes, food security and development, (ii) adapting and building resilience of agriculture and food security systems to climate change at multiple levels, and (iii) reducing and/or removing greenhouse gases emissions from agriculture(including crops, livestock and fisheries) and where possible. CSA invites to consider these 
three objectives together at different scales from farm to landscape at different levels from local to global and over short and long time horizons, taking into account national and local specificities and priorities. CSA approaches entail greater investment in (i) managing climate risks, (ii) understanding and planning for adaptive transitions that may be needed, for example into new farming systems or livelihood, and (iii) exploiting opportunities for reducing or removing greenhouse gases emissions where feasible.

Department of Agricultural Extension services have been disseminating information and knowledge related to CSA. Review of relevant literatures provides some information on a plethora of practices and technologies. For example, soil management can help mitigate climate changel through a range of interventions (Smith et al., 2008). Alternate wetting and drying methods in such systems is not only save water, but also result in greatly reduced methane emissions (Sander et al., 2016). In addition, irrigation strategies that reduce the amount of water required can reduce energy consumption for pumping, thereby reducing emissions (Lampayan et al., 2015). Scholars reported that directly and indirectly growers have been using CSA. However, it lacks research and documentation on CSA in country CSA profile and CSA manual. It is reasonably important to understand a range of basic questions/issues revolving CSAto practically implement CSA: what is different about CSA, what key CSA priorities of farmers and scientists are, and what actions are needed to implement CSA.This study is based on a couple of questions like what are the agro-region based climate change hot spots of Bangladesh along with applied practices and technologies to CSA, what contributions being made by the practices and technologies of CSA, how institutional involvements promoting practices and technologies for adaptation and mitigation ofof Climate change impacts and application of CSA?

In Bangladesh, a little research has been found about the CSA practices and technologies. To find out the answer of the questions mentioned above, thisstudy is designed with the following objectives (i) understanding contributions of broad practices and technologies to CSA, (ii) determining agro-region based climate change hot spots in Bangladesh with specific reference toCSA practices and technologies, (iii) understanding institutional involvement in promoting practices and technologies for adaptation and mitigationof Climate change impacts and application of CSA.
Methodology

This study is largely based on past literature review, despite primary data and information was collected from Agricultural Extension Officers. A series of discussions were conducted with Upazila Agriculture Officers of the concerned upazila along with Agricultural Extension Officers (AEOs), Bangladesh Center for Advance Studies (BCAS) personnel, and expert in the relevant field, which made a good support to write this paper. Secondary data were collected from books, journals, discussion paper and research reports, the World Bank Development report, FAO publications, and ADB working papers. Exploring pertinent CSA literature in the website also assisted a lot to document and presents this study. The study was carried out in the Department of Agricultural Extension\& Information Systems, Sher-e-Bangla Agricultural University, Dhaka during April to July 2017.

\section{Results and Discussion}

\section{Contributions of the broad practices and technologies to $C S A$}

CSA practices and technologies in the crop subsector are broadly included in soil management, crop management, water management, agroforestry and energy management.

\section{Soil management}

Good soil health is essential for sustainable and productive agriculture. đ́Healthyôsoil helps to produce a good amount of crop production even in the context adverse climatic condition. Key aspects of ónealthyô soil include (i) a comprehensive soil covers of vegetation (ii) minimal loss of soil nutrients from the soil through leaching, (iii) zero or minimal rates of rainfall run-off and soil erosion, and (iv)no accumulation of contaminants in the soil. It is estimated that more than $100 \mathrm{~kg}$ nutrients per ha a year are getting out of the soil system (FAO, 2015). Bangladesh also has wide variety and complexity of soils at short distances due to a diverse nature of physiographic condition, parent materials, lands, and hydrology and drainage conditions. Due to intensive cropping to grow more food, continuous changes are taking place in the soil fertility status due to organic matter depletion, nutrient deficiencies, drainage impedance/water logging followed by degradation of physical and chemical properties of soil as well as salinity/acidity occurred due to climate change effects . Soil management contributes to CSA in a numerous way (Table 1). 


\section{Crop management}

There are many ways of crop management that can be treated as climate-smart. Crop production by adopting diverse farming systems are subject to widely differing socio-economic, climatic and soil conditions. Moreover, increasing attention is now being given to the wide range of crop production practices that can be considered as álimate-smartôeither from an adaptation perspective, or for their mitigation potential. For example, crop interventions, like drought tolerance and shorter-duration varieties, can substantially reduce the risk of yield reduction or crop failure (Roy and Chan, 2014) (Table 1).

\section{Water management}

Bauman et al. (2007) estimated that agriculture is the largest consumer of the world's freshwater resources, requiring $70 \%$ of available supply of which almost $40 \%$ are used for rice production. Accordingly, water stress has becoming a vital issue, in general, for agriculture and in particular, for rice production. In Bangladesh, occurrence of drought in the northwest region due to climate change is an alarming issue that should be addressed through water management practices. Flood, flash flood is also common in middle and north east that needs proper drainage system. Promoting water use efficiency, water management has huge potential for mitigation in rice cultivation. A range of contributions of water management to CSA have been reported (Table 1) in the recent literature such as Climate-Smart Sourcebook of FAO.

\section{Agro forestry}

Agro forestry is one of the vital management options for climate change mitigation throughboosting carbon sequestration by increasing biomass both above and below ground. Key strategies include increasing tree cover (afforestation and reforestation) and reducing deforestation and degradation for climate change mitigation and adaptation. Table 1 presents main contribution of agro forestry to CSA.

\section{Energy management}

Energy plays an essential role in the pre-production stage of inputs; in the production of crops, and forestry products; in post-production and postharvest operations; in food storage and processing; in food transport and distribution; and in food preparation. These systems require (i) direct energy, namely, electricity, mechanical power, solid, liquid and gaseous fuels; and (ii) indirect energy like the energy required to manufacture inputs such as machinery, farm equipment, fertilizers and pesticides (FAO 2012). It is, therefore, efficient management of energy sources and diversification through the use of sustainable renewable energy can reduce reliance on fossil fuels, increase energy supply and access, and reduce the impact on agriculture/environment (Table 1). A couple of energy management interventions can be adopted such as (i) increasing energy efficiency, (ii) generating a supply of renewable energy from the sector, and (iii) broadening access to modern energy services (FAO 2013).

\section{Agro-region based climate change hot spots of Bangladesh}

Around $41 \%$ of countryôs total area is under climate risk which is gradually being heightened in the contemporary development discourse (Mandal 2016). Literature (e.g., MoEF, 2005) review indicates that the major climate risk hotspots in Bangladesh are:

- Cyclone risk hotspots: The cyclone starts from Bay of Bengal and damage crops, vegetation and lead to floods and storm surges. South, south east-west region, i.e. Coxôs Bazar, Chittagong, Patuakhali, Barguna, Sathkhira, Khulna districts in Bangladesh are vulnerable to cyclone and storm surges. Violent cyclone Sidr(2007), Aila (2009), Nargis,Mohasen heated those districts caused serious damage and losses.

- Flash-flood and flood risk hotspots: North and north east regions, namely, Sunamganj, Moulavi Bazaar, Hobiganj, Sylhet districts are flash-flood prone areas. Erratic and uneven rainfall caused by climate change results in sudden flood in those areas make damages in standing crops, vegetation, soil erosion, livestock and poultry. Middle regions namely Manikganj, Munshiganj, Tangail, Dhaka, Comilla, Brahmanbaria districts are flood prone areas where serious loss of crops and vegetables are accounted frequently.

- Drought risk hotspots: Mainly located in northern west region which includes, Rajshahi, Chapainawabganj (Barind tract), Kurigram, Nilphamari, Rangpur and Dinajpur districts. Rice and other crop production are seriously hampered in those areas due to scarcity of irrigation water.

- Salinity risk hotspots: Coastal belt south and south west regions are identified as salinity vulnerable areas. It is reported that salinity has already been penetrated in 100 kilometer north to the South west coast. Patuakhali, Barguna, Sathkhira, Khulna, Pirojpur and Gopalganj districts are being reported as the salinity affected areas where local rice variety, rice other than saline tolerant varieties, vegetables are difficult to produce. Reviewing DAE documents revealed that there are manyCSA technologies and practices have been used in different regions. These technologies and practices mainly used in agriculture sector especially in the crop subsector (Table 2). 
Table 1. Understanding contributions of broad practices and technologies to climate-smart agriculture

\begin{tabular}{|c|c|c|c|}
\hline $\begin{array}{l}\text { CSA practices } \\
\& \text { technologies }\end{array}$ & roductivity & Adaptation & Mitigation \\
\hline $\begin{array}{l}\text { Soil } \\
\text { management }\end{array}$ & $\begin{array}{l}\text { Improving soil fertility, } \\
\text { water availability and } \\
\text { reducing the loss of } \\
\text { nutrient-rich topsoil that } \\
\text { improves productivity. }\end{array}$ & $\begin{array}{l}\text { Interventions like reducing } \\
\text { the risks of run-off, contour } \\
\text { ploughing, and land terracing } \\
\text { act as adaptation measures. }\end{array}$ & $\begin{array}{l}\text { Soils are an important below } \\
\text { ground ósinkô for carbon } \\
\text { sequestration. Interventions are } \\
\text { organic matter additions, and } \\
\text { inclusion of trees in crop fields, } \\
\text { etc. }\end{array}$ \\
\hline $\begin{array}{l}\text { Water } \\
\text { management }\end{array}$ & $\begin{array}{l}\text { Reduce crop water stresses } \\
\text { by capturing and retention } \\
\text { of rainfall, improving } \\
\text { schedule of irrigation water } \\
\text { boosts productivity. }\end{array}$ & $\begin{array}{l}\text { Greater water use efficiency } \\
\text { or improved irrigations } \\
\text { systems (e.g. supplemental } \\
\text { irrigation) are an important } \\
\text { longer-term } \\
\text { mechanism. }\end{array}$ & $\begin{array}{l}\text { Alternate wetting and drying } \\
\text { cycles and, irrigation strategies } \\
\text { that reduce the amount of water } \\
\text { required can reduce energy } \\
\text { consumption for pumping, } \\
\text { thereby reducing emissions }\end{array}$ \\
\hline $\begin{array}{l}\text { Crop } \\
\text { production/ } \\
\text { Mangement }\end{array}$ & $\begin{array}{l}\text { Breeding of higher yielding } \\
\text { crops, adopting improved } \\
\text { nutrient management, and } \\
\text { cultivating disaster-resilient } \\
\text { varieties increase } \\
\text { productivity. }\end{array}$ & $\begin{array}{l}\text { Crop interventions can } \\
\text { reduce the risk of yield } \\
\text { reduction. Developing and } \\
\text { planting of heat-tolerant, } \\
\text { drought-tolerant or salinity- } \\
\text { tolerant crop varieties. Crop } \\
\text { rotation, change in cropping } \\
\text { pattern, relay, intercropping } \\
\text { or zero tillage cropping are } \\
\text { good adaptation practices. }\end{array}$ & $\begin{array}{l}\text { Mitigation potential of crop } \\
\text { production largely stems from } \\
\text { soil and water management, or } \\
\text { the agroforestry systems. } \\
\text { Perennial crops are able to } \\
\text { sequester greater amounts of } \\
\text { carbon below ground than } \\
\text { annual crops. }\end{array}$ \\
\hline Agrof & $\begin{array}{l}\text { Agroforestry provides } \\
\text { various ecosystem services } \\
\text { like addition income, } \\
\text { improves soil quality, etc } \\
\text { that leads productivity }\end{array}$ & $\begin{array}{l}\text { Agroforestry practices } \\
\text { increase the absorptive } \\
\text { capacity of soil and reduce } \\
\text { evapotranspiration, and used } \\
\text { as shelterbelts and } \\
\text { windbreaks. }\end{array}$ & $\begin{array}{l}\text { Actions that increase tree cover } \\
\text { and reduce deforestation and } \\
\text { degradation, increase carbon } \\
\text { sequestration through increased } \\
\text { biomass both above and below } \\
\text { ground. }\end{array}$ \\
\hline $\begin{array}{l}\text { Energy } \\
\text { management }\end{array}$ & $\begin{array}{l}\text { Productivity can be } \\
\text { increased through } \\
\text { improving energy } \\
\text { efficiency, reducing losses } \\
\text { and diversifying energy } \\
\text { sources, e.g. the use of } \\
\text { renewable energy sources. }\end{array}$ & $\begin{array}{l}\text { Reducing reliance on fossil } \\
\text { energy and associated costs, } \\
\text { and sustainable means of } \\
\text { usage of biomass. Other } \\
\text { adaptation benefits are } \\
\text { improved health and } \\
\text { increased food security. }\end{array}$ & $\begin{array}{l}\text { Bioenergy and solar energy can } \\
\text { replace fossil fuels. Energy } \\
\text { management like identifying } \\
\text { sustainable renewable energy } \\
\text { resources, promoting efficient } \\
\text { and replicable technologies are } \\
\text { effective mitigation measures. }\end{array}$ \\
\hline
\end{tabular}

Source: FAO, 2010; FAO, 2013; Roy, 2015; FAO, 2015; Chan et al., 2016 
Table 2. Some area specific technology

\begin{tabular}{|l|l|}
\hline Technology/Practice & Applicable regions \\
\hline Alternate wetting and drying & Barind tract/North west drought prone areas,likeRajshahi, Chapanawabganj. \\
\hline $\begin{array}{l}\text { Construction of mini-pond in } \\
\text { crop field }\end{array}$ & North and northwest like Rajshahi, Rangpur and Dinajpur districts. \\
\hline $\begin{array}{l}\text { Cultivation of less water } \\
\text { loving crops }\end{array}$ & North and northwest like Rajshahi, Rangpur and Dinajpur districts. \\
\hline Zero or minimum tillage & Flood prone areas like, Tangail, Manikgonj,Munshiganj districts. \\
\hline Sarjan method cultivation & $\begin{array}{l}\text { Southern regions like Barisal, Patuakhali, Barguna, Pirojpurdistricts,Salinity } \\
\text { prone areas Barisal, Patuakhali, Barguna, Pirojpurdistricts,Salinity prone } \\
\text { Chittagong,Coxesbazar. }\end{array}$ \\
\hline Floating garden & $\begin{array}{l}\text { Flood prone or water logged areas like Sonamganj, Habiganj, Bhrahmanbaria, } \\
\text { Pirojpur districts. }\end{array}$ \\
\hline
\end{tabular}

Source: DAE, 2011

Although several practices and technologies of CSA have been applying by farmers, sometimes their knowledge and perception are insufficient that can have long-lasting effects on crop production.

A survey conducted by Upazila agriculture officer of Amtali, Barguna, revealed that although people understand that the climatic is changing but they are not so accustomed to the term climate-smart agriculture (Table 3).

Table 3. Distribution of respondents according to their awareness to climate smart agriculture

\begin{tabular}{|l|l|l|}
\hline Categories & Number & Percent \\
\hline Aware & 40 & 40 \\
\hline Not aware & 60 & 60 \\
\hline Total & 100 & 100 \\
\hline
\end{tabular}

Source: Badrul, 2014

It is difficult to find available studies that indicate to what extent farmers used CSA practices and technologies. A report made by Mr. Dr.Md. Rafiqul Islam (an extension expert) in 2014, stated that $48 \%$ farmers have practiced CSA (Table 4).

Table 4. Distribution of respondents according to their application status of climate smart technology being practiced as local adaptation knowledge

\begin{tabular}{|l|l|l|}
\hline Categories & Number & Percent \\
\hline Apply & 48 & 48 \\
\hline Donâ Apply & 52 & 52 \\
\hline Total & 100 & 100 \\
\hline
\end{tabular}

Source: Rafiqul, 2014

\section{Mapping out Institutional Involvement in promoting Practices and Technologies for Adaptation and Mitigation of Climate change impacts and application of CSA.}

Government of Bangladesh has formulated National Adaptation Plan of Action (NAPA) along with climate change trust fund for an amount of BDT7000 million. Ministry of Environment and Forest (MoEF) has been looking after the national and international policy issues and funding sources. Ministry of Agriculture, Ministry of Livestock and Fisheries through DAE, DLS and DOF have been implementing the technology and practices relevant to CSA. Under the National Agricultural Research System (NARS), the institutes like BARI, BRRI, BJRI, SRTI, have been devotedly involved in inventing new technology and practices supporting CSA approach.Major Government Departments directly and or indirectly involved in CSA issues are being represented in Table 5.

\section{Role of Department of Agricultural Extension (DAE) on disseminating CSA practices}

Under the Ministry of Agriculture, DAE Implemented a project titled, ñSupplementary Irrigation in Drought Prone Areas in Transplanted Aman Crop (SIDATAC)ò during the period1998-2004. That had been implemented in 254 Upazilas of 46 Districts covering 4 million hectares of Transplanted Aman rice land. The main activities were, a) Media Campaign, b) Publication, c) Demonstration and Field days. d) Training, e) Mini Meteorological Lab, f) Workshop/ seminar, g) Fractional pump supply, h) Plastic pipe supply, i) Block Fund for Diesel and Electricity. 
Table 5. Major govt. Departments involved in climate change, food security and socio-economic livelihood in Bangladesh that support CSA practices.

\begin{tabular}{|l|l|}
\hline Government Department & Major Roles and Responsibilities \\
\hline $\begin{array}{l}\text { Department of Environment and } \\
\text { Forest (DOEF) }\end{array}$ & $\begin{array}{l}\text { - Policy formulation and implementation. } \\
\text { - Negotiation with Developed countries. } \\
\text { - Funding like Climate change trust fund, Green climate fund etc. }\end{array}$ \\
\hline DAE, DLS, DOF & $\begin{array}{l}\text { - Disseminating new technology and practices. Increasing production and } \\
\text { productivity in crop, livestock and fisheries subsector. Income generation, } \\
\text { livelihood improvement of farming community. }\end{array}$ \\
\hline $\begin{array}{l}\text { NARS } \\
\text { (BARI, BRRI, BJRI, SRTI) }\end{array}$ & - Involved in inventing new technology and practices supporting CSA approach. \\
\hline Department of Food & - Food storage distribution and pricing leading to food security. \\
\hline Water Development Board & $\begin{array}{l}\text { Deals with water and hydrology, protection of river erosion, water shed } \\
\text { management, Flood forecasting and early warning. }\end{array}$ \\
\hline $\begin{array}{l}\text { Bangladesh Meteorological } \\
\text { Department }\end{array}$ & $\begin{array}{l}\text { Deals with weather and climate forecasting, which are the basic components of } \\
\text { climate change, food security, and livelihood. }\end{array}$ \\
\hline
\end{tabular}

Another project, Support to the Strengthening for Disaster Preparedness in Agriculture Sector (SSDP) had been implemented in the year, 2004-2005. At that time formal introduction of Disaster Risk Management (DRM) had been taken place in DAE with technical support from FAO. Main objective was to capacitate the DAE in DRM. The project had been implemented in 4 Upazilas under 2 drought and flood prone districts.

In the year 2005-2007, DAE implemented Livelihood Adaptation to Climate Change Project (LACC I), under the Technical support from FAO. The specific objective of the project was how climate change impact can be addressed in local and regional level. Report revealed that:

- 26 Adaptation options identified from the farmers and other stakeholders,

- More than 300 demonstrations on different CSA technologies had been implemented and after field testing more suitable and user friendly technologies were identified.

- The other Partners of the project were Bangladesh Agriculture Research Institute (BARI), Bangladesh Rice Research Institute (BRRI), Asian Disaster Preparedness Centre, Bangkok (ADPC).

During the year 2008-2009 a project titled Livelihood Adaptation to Climate Change (LACC) phase-II had been implemented by the Department of Agricultural Extension (DAE) under the Technical Assistance from FAO. It was a follow up project of LACC-I. The project had been implemented in 10 Upazilas, out of which 6 were selected from drought prone areas and 4 were from coastal areas.

A total number of 800 adaptation technologies had been demonstrated during the project period. At that tenure 88 adaptation options were validated out of which the following technologies being recommended as CSA approach based on level of acceptance that are being represented in Table 6.

A program titled ñDissemination of floating bed vegetable and spices cultivation technology as an adaptation technique of climate change impact in the flood and water logged prone areas of Bangladeshò is ongoing at DAE. The program is being financed under the Climate Change Trust fund project under the Ministry of Environment and Forest. 
Table 6. Acceptance level of some adaptation and mitigation practices in climate change victim regions

\begin{tabular}{|c|c|c|c|c|c|c|}
\hline Categories & Adaptation practices & Season & $\begin{array}{l}\text { Source of } \\
\text { validation }\end{array}$ & $\begin{array}{c}\text { Frequency } \\
\text { of test }\end{array}$ & Regions & Acceptance \\
\hline $\begin{array}{l}\text { Agronomic } \\
\text { management }\end{array}$ & $\begin{array}{l}\text { Manual closing of } \\
\text { soil cracks }\end{array}$ & Rabi & Farmers & 1 & Drought & Low \\
\hline$"$ & Ail lifting & Kharif-II & Farmers & 1 & Drought & Low \\
\hline " & $\begin{array}{l}\text { Cultivation of early } \\
\text { rice varieties }\end{array}$ & $\begin{array}{c}\text { Rabi } \\
\text { \&Kharif- } \\
\text { II }\end{array}$ & $\begin{array}{l}\text { Community } \\
\text { and DAE }\end{array}$ & 1 & Drought & Moderate \\
\hline$"$ & $\begin{array}{l}\text { Cultivation of short } \\
\text { duration rice } \\
\text { varieties }\end{array}$ & $\begin{array}{c}\text { Rabi } \\
\text { \&Kharif- } \\
\text { II }\end{array}$ & $\begin{array}{l}\text { Community } \\
\text { and DAE }\end{array}$ & 1 & Drought & Moderate \\
\hline Saline tolerance & $\begin{array}{l}\text { Cultivation of saline } \\
\text { tolerant vegetable } \\
\text { crops }\end{array}$ & All & $\begin{array}{l}\text { Community } \\
\text { and DAE }\end{array}$ & 1 & $\begin{array}{l}\text { Coastal } \\
\text { saline }\end{array}$ & High \\
\hline $\begin{array}{l}\text { Water } \\
\text { harvesting }\end{array}$ & $\begin{array}{l}\text { Excavation of mini } \\
\text { pond }\end{array}$ & Kharif-I & BMDA* & 5 & Drought & very high \\
\hline $\begin{array}{l}\text { Water } \\
\text { harvesting }\end{array}$ & $\begin{array}{l}\text { Supplementary } \\
\text { irrigation }\end{array}$ & Kharif-II & $\begin{array}{l}\text { Farmers, } \\
\text { DAE }\end{array}$ & 1 & Drought & Very high \\
\hline $\begin{array}{l}\text { Water use } \\
\text { efficiency }\end{array}$ & Rice intensification & Rabi & Experts & 1 & Drought & Low \\
\hline $\begin{array}{l}\text { Water use } \\
\text { efficiency }\end{array}$ & $\begin{array}{l}\text { Alternate wetting } \\
\text { and drying }\end{array}$ & Rabi & Experts & - & - & - \\
\hline $\begin{array}{l}\text { Crop } \\
\text { intensification }\end{array}$ & $\begin{array}{l}\text { T.Aman- } \\
\text { Mustard/linseed }\end{array}$ & $\begin{array}{l}\text { Kharif-II } \\
\text { \& Rabi }\end{array}$ & BARI/BRRI & 1 & Drought & Moderate \\
\hline$"$ & T.Aman-Chickpea & $\begin{array}{l}\text { Kharif- } \\
\text { II\& Rabi }\end{array}$ & BARI/BRRI & 3 & Drought & Moderate \\
\hline " & T. Aman-Mungbean & $\begin{array}{l}\text { Kharif-II } \\
\text { \& Rabi }\end{array}$ & DAE & 2 & Drought & Moderate \\
\hline $\begin{array}{l}\text { Alternate } \\
\text { enterprise/ } \\
\text { technologies }\end{array}$ & Jujube gardening & Kharif-1 & Experts & 5 & All & Very high \\
\hline $\begin{array}{l}\text { Environmental } \\
\text { protection/ } \\
\text { mitigation }\end{array}$ & $\begin{array}{l}\text { Timber and fruit tree } \\
\text { cultivation along the } \\
\text { roadside }\end{array}$ & All & Community & 0 & $\begin{array}{l}\text { Coastal } \\
\text { saline }\end{array}$ & Not assessed \\
\hline
\end{tabular}

* Barendra Multipurpose Development Authority

Source: LACC-DAE, 2011 


\section{Climate Field Schools (CFS) for CSA in Bangladesh}

DAE made a partnership with multidonor UN financed project titled ñDisaster and Climate Risk Management in Agriculture (DCRMA), under Comprehensive Disaster Management Project (CDMP) Phase-II during the period from 2010-2014. Donors (UNDP, UK AID, EU, Norwegian Embassy, Sweden and Australian AID) were involved with the Government of Bangladesh for conducting several projects. The specific objective of DCRMA project was to increase DAE capacity to cope with climate change impacts. The project had been implemented 26 districts of Bangladesh covering all the climate change hotspots. During this period, Union Disaster Management Committee (UDMC) was established at local level.

One of the main achievements of the project was to conduct Climate Field Schools (CFS) at the targeted 52 Upazilas. CFS is such a Non-Formal Educational (NFE) arrangement to capacitate the farmers as to improve their socio-economic conditions by acquiring expertise on combating the effects of climate change in agriculture. In this connection, 156IPM/ICM clubs were selected where there was participation of 25 male-female farmers in each club.

Objectives of CFS were:

- To make aware of the farmers to keep the impacts of climate change at minimum level,

\section{References}

Ahmed M, Suphachalasai S. 2014. Assessing the Costs of Climate Change and Adaptation in South Asia. Asian Development Bank, the Philippines, 163 p.

Badurl SM. 2014. A survey on determining farmers awareness on climate smart agriculture, An unpublished official document, by Upazila Agriculture Officer, Amatali Barguna.

Bouman BAM. 2007. Adoption and economics of alternate wetting and drying water management for irrigated lowland rice. F Crop Res. 170: 95ї 108.

Chan, NW, Roy R and Chaffin, BC. 2016. Water Governance in Bangladesh: An Evaluation of Institutional and Political Context. Water, 8, 403421.

DAE. 2011. Annual report (unpublished) by Department of Agricultural Extension Khamarbari, Dhaka
- To capacitate the farmers to address the challenges of climate change

- To increase the self-confidence of farmers on the face of adverse effects of climate change

- To prepare the farmers to understand the forecast of disasters and climate change

- Learning by doing, and

- To help the farmers to be cooperative and socialistic.

Four stages of CFS implementation are baseline survey, input supply, technology demonstration and conduction of session. Sessions were conducted in the drought prone, flood, flash flood prone and salinity areas following a definite schedule and lesson plan.

\section{Involvements of NGOs in CSA}

Non-Government Organizations such as Bangladesh Centre for Advanced Studies (BCAS), Christian Aid, Practical action, Bangladesh Paribas Andolon (BAPA), Bangladesh Environmental Lawyers association (BELA)and Bangladesh Rural Advancement committee (BRAC).have been working and dealing with food security, environment, and socioeconomic livelihood in Bangladesh. There initiatives addresses three interlinked issues like productivity, adaptation and food security that is a big support to CSA.

FAO. 2013. Climate-Smart Agriculture: Sourcebook. Rome, Italy: Food and Agriculture Organization of the United Nations, $570 \mathrm{p}$.

FAO. 2015. Climate-Smart Agriculture: A call for action. Synthesis of the Asia-Pacific Regional Workshop, Bangkok, Thailand, 18 to 20 June 2015. A source book, $57 \mathrm{p}$.

LACC-DAE. 2011. Livelihood Adaptation to Climate Change, Department of Agricultural Extension, Documents review LACC-1 \& II project DAE.

Lampayan RM, Rejesus RM, Singleton GR, Bouman BAM. 2013. Adoption and economics of alternate wetting and drying water management for irrigated lowland rice. F Crop Res. 170: 95ї 108.

Mandal S. 2016. Climate is changing: Food and Agriculture must too: A key note paper presented by M.A Sattar Mandal, in the seminar organized by Ministry of Agriculture, during World Food day 16th Octoberỗ016. 
MoEF 2005. National Adaptation Programme of Action. Final Report. 2005, UNFCCC, 65 p.

Rafiqul I. 2014. A report on adoption of climate Smart Agriculture technology by the farmers of project areas of LACC project.

Roy R, Chan NW, Uemura T, Imura H. 2013. The vision of agri-environmental sustainability in Bangladesh: How the policies, strategies and institutions delivered? Journal of Environmental Protection, 4, $40 і ̈ 51$.

Roy R, Chan NW. 2014. A multi-level evaluation of policy integration of human resource development in agriculture sector. Natural Resource. 5, 11910129

Roy R, Chan NW, Xenarios S. 2015. Sustainability of rice production systems: An empirical evaluation to improve policy. Environ. Dev. Sustain. 18, 257ï 278.

Roy R. 2015. Modelling and policy integration of sustainable rice farming systems in Bangladesh. PhD Thesis, University Sains Malaysia, 269 p.

Sander BO, Wassmann R, Siopongco JDLC. 2016. Water-saving techniques: potential, adoption and empirical evidence for mitigating greenhouse gas emissions from rice production. CABI Climate Change Series, pp. 193-207

World Bank. 2012. Turn Down the Heat. Why a $4^{\circ} \mathrm{C}$ Warmer World Must Be Avoided. The World Bank, Washington, DC, USA, 106 p. 